\title{
COMMENTS
}

\section{Implications of the Private Securities Litigation Reform Act of 1995 for Judicial Presumptions of Market Efficiency}

\author{
Nathaniel Carden $\dagger$
}

Over the past twenty years, the efficient capital market hypothesis ("ECMH") has risen to a prominent position in financial and economic theory. ${ }^{1}$ In its most commonly held form-known as "semi-strong"-the ECMH states that the securities markets incorporate all available public information so rapidly that investors cannot develop a trading rule (including one based on research into company or industry fundamentals) that will systematically yield greater returns than the market. Recently, however, theorists have increasingly questioned the ECMH. These theorists argue that irrational behavior and limited informationprocessing abilities can keep the price of securities at levels that do not reflect their fundamental values. ${ }^{2}$

† B.S.B.A. 1996, Georgetown University; J.D. Candidate 1999, The University of Chicago.

1 See, for example, Donald C. Langevoort, Theories, Assumptions, and Securities Regulation: Market Efficiency Revisited, $140 \mathrm{U} \mathrm{Pa} \mathrm{L} \mathrm{Rev} \mathrm{851,} 853$ (1992) ("[T]here is no other proposition in economics which has more solid empirical evidence supporting it than the Efficient Market Hypothesis."), quoting Michael C. Jensen, Some Anomalous Evidence Regarding Market Efficiency, $6 \mathrm{~J}$ Fin Econ 95, 95 (1978).

2 See Edward S. Adams and David E. Runkle, Solving a Profound Flaw in Fraud-onthe-Market Theory: Utilizing a Derivative of Arbitrage Pricing Theory to Measure Rule 10b5 Damages, 145 U Pa L Rev 1097, 1112 (1997) (noting "aggregate ambiguity" in studies attempting to verify the ECMH); Langevoort, $140 \mathrm{U} \mathrm{Pa} \mathrm{L} \mathrm{Rev} \mathrm{at} \mathrm{853-54} \mathrm{(discussing} \mathrm{the} \mathrm{rise}$ of "noise theory"); Lynn A. Stout, Are Stock Markets Costly Casinos? Disagreement, Market Failure, and Securities Regulation, 81 Va L Rev 611, 648-50 (1995) (noting that financial theorists have become increasingly skeptical of the efficient market hypothesis). See also In re LTV Securities Litigation, 88 FRD 134, 145 n 7 (N D Tex 1980) ("[E]ven among aca- 
Despite this emerging debate, most courts and legal commentators have remained steadfastly committed to the ECMH. ${ }^{3}$ The Supreme Court, for example, employed the ECMH in the influential case Basic Inc $v$ Levinson. ${ }^{4}$ In Basic, the Court endorsed the "fraud-on-the-market" theory in private actions under Securities and Exchange Commission ("SEC") Rule 10b-5. By assuming the existence of an efficient market, the Court allowed groups of investors to sue without showing individualized reliance upon the fraudulent statement.

In 1995, however, Congress passed the Private Securities Litigation Reform Act of 1995 ("PSLRA"). ${ }^{6}$ The measure was designed to stem what Congress believed to be an epidemic of frivolous securities fraud suits. The concern was that any time a company experienced a decline in its share price it could faceand could be debilitated by-a 10b-5 suit alleging fraud or misinformation. Hoping to quell such meritless litigation, Congress enacted a provision that caps the amount plaintiffs can recover in damages. This limit on damages was in response to the possibility that markets might overreact when the fraud is disclosed. Thus, the PSLRA indicates a congressional skepticism of the ECMH.?

This Comment argues that the PSLRA provides evidence of congressional distrust of the $\mathrm{ECMH}$, and that courts-institutions that are less technically proficient and less democratically accountable than Congress-should defer to Congress's skeptical view. Accordingly, courts should reassess the several common law

demics, the strongest proponents of the efficient market hypothesis, there are some doubts.").

${ }^{3}$ See, for example, Michael Y. Scudder, Comment, The Implications of Market-Based Damages Caps in Securities Class Actions, $92 \mathrm{Nw}$ U L Rev 435, 474 (1997) (arguing that “[m]arket efficiency has essentially become a truism"); Stout, $81 \mathrm{Va} \mathrm{L} \mathrm{Rev} \mathrm{at} 648$ (cited in note 2) (noting the "great popularity" of the hypothesis in the legal culture).

4485 US 224, 245-47 (1989) (allowing a class of defrauded plaintiff stockholders to enjoy a rebuttable presumption of reliance upon the defendants allegedly misleading statements).

s 17 CFR \& 240.10b-5 (1997). In relevant part, the Rule reads:

It shall be unlawful for any person, directly or indirectly, by the use of any means or instrumentality of interstate commerce, or of the mails or of any facility of any national securities exchange...

(b) To make any untrue statement of a material fact or to omit to state a material fact necessary in order to make the statements made, in the light of the circumstances under which they were made, not misleading.

- Pub L No 104-67, 109 Stat 737, codified at 15 USCA $\$$ 77z-1 to 78u-5 (Supp 1995).

$\because 15$ USC \& 78u-4(e) (limiting damages to the difference between the purchase price and mean trading price of the security during the ninety day period following the disclosure of corrective information). 
doctrines, such as fraud-on-the-market, that rest on the ECMH. Part I surveys courts' recent uses of the ECMH. This Part delineates three distinct uses of "efficiency": (1) as a goal for the market, (2) as a description of the market, and (3) as a heuristic device $^{8}$ needed because of courts' limited competence in predicting market movements. Part II analyzes the text, legislative history, and policy goals of the PSLRA, focusing on those aspects most relevant to market efficiency. This Part contends that in promulgating the PSLRA, Congress did not adhere to any particular financial theory; rather, it took a purely pragmatic approach to securities litigation. There is thus a sharp contrast between Congress's approach in the PSLRA and the manner in which courts use descriptive efficiency.

Next, in Part III this Comment proposes an approach that reconciles this conflict. It concludes that courts should follow Congress's lead and limit reliance upon the ECMH. Instead, courts should develop a doctrine grounded less in finance and more in policy and probability. This approach to the problem of securities fraud would better utilize both the courts' institutional competence (particularly in factfinding and assessing credibility) and the "common sense" foundation of the theory described by the Supreme Court in Basic. ${ }^{9}$

\section{I. “COMMON LAW” DOCTRINES PREMISED ON THE ECMH}

Courts handling securities litigation use the notion of efficiency in several ways. These uses fall into three general categories. First, efficiency is often a normative goal. Certain judicial decisions attempt to make the capital markets more efficient. Second, efficiency is sometimes a purely descriptive term that characterizes the operation of the capital markets. Here, judicial decisions rest (or claim to rest) on a presumption about the existing state of the market. Third, when calculating damages, courts often use models that invoke concepts of market efficiency. In these cases, however, courts do not describe the market as efficient. Rather, given the courts' lack of expertise in the vagaries of the securities markets, they use the models because no better measurement device is available to them. This Part surveys these three general ways in which courts have relied on the ECMH.

8 In other words, courts use efficiency as a rule of thumb, rather than attempting to describe the market as efficient.

- 485 US at 246 (noting that the presumption of reliance is "supported by common sense and probability"). 


\section{A. Normative Efficiency: The Aim of Securities Regulation}

Courts often discuss efficiency as one of the primary justifications for disclosure obligations. ${ }^{10}$ In this context, the concept of efficiency is a normative goal: an efficient market is desirable because it ensures that society's productive assets are transferred to those who can make the best use of them, thereby maximizing aggregate welfare. ${ }^{11}$ If market participants are unable to acquire accurate information about a company's future prospects, then their assessments of returns from capital will be inaccurate. The result is too much investment in some firms (those that are able to inflate expectations through inaccurate statements) and too little in others (those that report accurately). ${ }^{12}$ In the normative context, then, the ECMH plays no role; efficiency is an aspiration for, not a hypothesis about, the financial markets.

\section{B. Descriptive Efficiency: Liability for Fraudulent Statements or Omissions}

The concept of efficiency also appears in securities litigation as an attempt to describe the functioning of the securities markets. One of the most important types of descriptive efficiency is the ECMH, which rose to prominence during the late 1970s and early 1980 s. $^{13}$ The ECMH predicts that financial markets digest information in such a manner as to preclude the development of a trading strategy that yields returns superior to those that can be earned by purchasing a diversified portfolio of shares. ${ }^{14}$

${ }^{10}$ See, for example, Shaw v Digital Equipment Corp, 82 F3d 1194, 1207 (1st Cir 1996) (noting that a "central goal" of the regulatory system is "to promote fairness and efficiency"); LHLC Corp v Cluett, Peabody \& Co, 842 F2d 928, 931 (7th Cir 1988) (arguing that consolidated information disclosure facilitates efficient capital allocation).

"See John F. Barry, III, The Economics of Outside Information and Rule 10b-5, $129 \mathrm{U}$ $\mathrm{Pa} L \mathrm{Rev} 1307,1317$ (1981) ("[The] continual redirection of capital from less promising to more promising pursuits benefits the investor and society as a whole because both maximize welfare by allocating scarce resources to investment opportunities promising the greatest return.").

${ }^{12}$ See In re LTV, 88 FRD at 145 ("Inaccurate information may result in skewed costs of capital.").

${ }^{13}$ See Lynn A. Stout, The Unimportance of Being Efficient: An Economic Analysis of Stock Market Pricing and Securities Regulation, 87 Mich L Rev 613, 621 (1988) ("[N]o other vision of efficiency has captured the hearts and minds of the securities culture to the degree that informational efficiency has.").

${ }^{14}$ There are two forms of descriptive efficiency: "information arbitrage" and "fundamental value" efficiency. The former posits that the market digests information and that share prices move in such a way as to prevent the use of public information to earn superior returns, while the latter relates to the market's ability to reflect properly the value of the assets underlying the traded security. See Eckstein $v$ Balcor Film Investors, 8 F3d 1121, 1129-30 (7th Cir 1993) (noting that in securities fraud cases "[w]e call a market 'efficient' because the price reflects a consensus about the value of the security being traded- 
There are three versions of the $\mathrm{ECMH}$, each making a progressively stronger claim. ${ }^{15}$ The first, known as the "weak" form, states only that past prices offer no indication of future price movements. Consequently, the weak form predicts that it is futile for investors to undertake so-called technical analysis based on patterns in historical price data. ${ }^{16}$ The intermediate version of the theory, termed "semi-strong," asserts that all publicly available information is reflected in market price, and that newly available public information becomes incorporated in that market price almost instantaneously. This version suggests that further "fundamental value" analysis, such as using information about the firm, the industry, or the economy, will not yield superior returns. Finally, the "strong" form maintains that all information, public and private, is fully incorporated into the market price at any given time. Under this theory, even insider trading would not be profitable.

Because securities litigation normally concerns misinformation, the weak form of the ECMH is not relevant for courts. Likewise, courts have rejected the strong form of the theory, ${ }^{17}$ as have most empirical studies. ${ }^{18}$ The semi-strong version, however, has

not necessarily because the price captures the true value of the firm's assets but because the price is the best available device to assess the significance of additional bits of information"). See also Baruch Lev and Meiring de Villiers, Stock Price Crashes and 10b-5 Damages: A Legal, Economic, and Policy Analysis, 47 Stan L Rev 7, 20-21 (1994) (distinguishing "informational" from "fundamental" efficiency); Daniel R. Fischel, Efficient Capital Markets, the Crash, and the Fraud on the Market Theory, 74 Cornell L Rev 907, 913 (1989) (contrasting "trading rule" with "value" efficiency). Because most securities fraud litigation brought under Section 10(b) and Rule 10b-5 involves passive investors who trade minority positions in the securities allegedly affected by the defendants' actions, information arbitrage efficiency is most germane to this Comment.

${ }^{15}$ This description of the three forms of the ECMH is taken from Fischel, 74 Cornell $\mathrm{L}$ Rev at 910-11.

${ }^{16}$ Burton G. Malkiel, A Random Walk Down Wall Street 137 (Norton 1990) (noting that if the weak form of the ECMH is true, "[t]echnical analysis is akin to astrology and every bit as scientific").

${ }^{17}$ See, for example, In re LTV, 88 FRD at 144 ("The price of the stock appears to reflect all publicly available information, but not all privately held information.”). More generally, liability under the fraud-on-the-market theory, see Part I.B.1, would make little sense if the market were strong-form efficient, because so long as it was known to anyone other than the defendants themselves, information correcting the allegedly misleading statement would also be reflected in the market price. Jonathan R. Macey and Geoffrey P. Miller, Good Finance, Bad Economics: An Analysis of the Fraud-on-the-Market Theory, 42 Stan L Rev 1059, 1078 (1990) (noting that "the strong form of the ECMH and the fraudon-the-market theory are fundamentally incompatible").

${ }^{18}$ See Fischel, 74 Cornell L Rev at 911 (citing empirical studies); id at $912 \mathrm{n} 11$ ("The empirical evidence to date (with some exceptions) appears to establish the validity of the weak and semi-strong but not the strong form of the efficient capital markets hypothesis."). 
been accepted by courts and become relevant to liability under Rule 10b-5.

\section{Fraud-on-the-market and the ECMH.}

The first and most important area in which courts use efficiency as a descriptive concept is the "fraud-on-the-market" theory. This theory developed out of a problem confronting plaintiffs in Rule 10b-5 litigation. Because these plaintiffs were generally investors holding passive positions, most individuals' losses were likely to be small. Consequently, no single investor could expect to benefit from bringing an action because, in all likelihood, the costs of litigation would far outweigh any potential recovery. Class action litigation offered a solution to this problem. By aggregating claims in a class action, it would be economically viable to pursue Rule $10 \mathrm{~b}-5$ suits that would serve as a private enforcement mechanism. ${ }^{19}$

However, the courts that inferred a private right of action from Rule $10 \mathrm{~b}-5^{20}$ used the traditional requirements of common law fraud in constructing such an action. ${ }^{21}$ Hence, plaintiffs were required to demonstrate actual reliance on the defendant's misleading statement (or omission). This requirement creates an obvious problem: to obtain class certification, plaintiffs must show that common questions of law and fact predominate, ${ }^{22}$ but reliance (almost by definition) is an individual matter.

By eliminating the need to prove individual reliance, the fraud-on-the-market theory facilitates class certification in securities litigation. ${ }^{23}$ In Basic, the Supreme Court described the fraud-on-the-market theory as creating a "rebuttable presump-

\footnotetext{
${ }^{19}$ See Basic, 485 US at 231 ("[The existence of] a private cause of action . . . constitutes an essential tool for the enforcement of the 1934 Act's requirements.").

${ }^{20}$ See id at 230-31; Ernst \& Ernst $v$ Hochfelder, 425 US 185, 196 (1976). See also Private Securities Litigation Reform Act of 1995, S Rep No 104-98, 104th Cong, 1st Sess 4 (1995), reprinted in 1995 USCCAN 679, 683 (" $[$ [C]ourts have held that Congress impliedly authorized such actions.").

${ }^{21}$ Generally stated, the elements of a Rule 10b-5 action are: (1) a material false or misleading statement or the omission of a fact necessary to make a statement not misleading; (2) scienter; (3) reliance by the plaintiff; (4) causation; (5) injury. In re Burlington Coat Factory Securities Litigation, 114 F3d 1410, 1417 (3d Cir 1997).

2 FRCP 23(b)(3). In addition to common questions of law and fact, a class action requires: (1) a class so large that joinder is impracticable, (2) a representative party with claims and defenses typical of the class, and (3) a representative party that will fairly and adequately protect the interests of the class. FRCP 23(a).

${ }^{23}$ Basic, 485 US at 242 ("Requiring proof of individualized reliance ... . would have prevented [the plaintiffs] from proceeding with a class action, since individual issues then would have overwhelmed the common ones.").
} 
tion of reliance"24 in circumstances where "materially misleading statements have been disseminated into an impersonal, welldeveloped market for securities. ${ }^{\$ 25}$ When the security in question trades in a market that meets the requisite conditions, the plaintiff is not required to demonstrate individualized reliance; class certification is therefore much easier. Importantly, the courts' understanding of "reliance" changes fundamentally under this theory. The fact that the purchaser bought in a developed securities market does not make that buyer's reliance on any particular statement probable, or even more likely. As a result, the inquiry no longer concentrates on whether the purchaser relied on the defendan's statements or omissions. ${ }^{26}$ Rather, as articulated by the Basic Court, the fraud-on-the-market presumption rests on the belief that "[a]n investor who buys or sells stock at the price set by the market does so in reliance on the integrity of that price. ${ }^{227}$

An earlier case that played a prominent role in the rise of the fraud-on-the-market theory also stated the importance of the market price to the investor. In In re LTV Securities Litigation, ${ }^{28}$ the court described the market as the "unpaid agent of the investor, informing him that given all the information available to it, the value of the stock is worth the market price. ${ }^{~ 29}$ In short, Basic and its forerunners invoke a descriptive notion of market efficiency, more specifically, the semi-strong version of the ECMH. Although the Basic Court's own language uses "efficient" only once in describing the securities market, ${ }^{30}$ it quotes language from another Rule 10b-5 case, Peil $v$ Speiser, ${ }^{31}$ that is essentially

${ }^{2}$ Id. Despite the Court's formulation, an inference of reliance is neither the only, nor even necessarily the most desirable, way of understanding fraud-on-the-market. See Part III.B. Whether the presumption is actually rebuttable is a contentious issue. See id at 256 $\mathrm{n} 7$ (White concurring in part and dissenting in part) (arguing that "rebuttal is virtually impossible in all but the most extraordinary case”); Fischel, 74 Cornell $L$ Rev at 918-19 (cited in note 14) (discussing the difficulties inherent in rebutting the presumption and concluding that it is "for all practical purposes . . . non-rebuttable"). The Basic majority suggests that the presumption might be rebutted through a showing that corrective disclosures counteracted the price effects of the initial misstatements. See Basic, 485 US at 248-49. See Parts I.B.2 and III.C for further discussion of this view.

${ }^{25}$ Basic, 485 US at 247.

* If the misrepresentation deflates the share price, then sellers who received a lower price as a result of the fraud may also recover-this was the situation in Basic itself. 485 US at 228. Analytically, the situations are identical, so this Comment will concentrate on the more common case of the allegedly defrauded buyer.

${ }^{27}$ Id at 247 (emphasis added).

28 FRD 134 (N D Tex 1980).

2 Id at 143.

${ }^{30} 485$ US at 249 n 29 (discussing "the assumption that Basic shares are traded on a well-developed, efficient, and information-hungry market").

${ }^{31} 806$ F2d 1154 (3d Cir 1986). 
a verbatim recitation of the semi-strong ECMH: "[T] company's stock is determined by the available material information regarding the company and its business. ${ }^{\text {.32 }}$ The Basic Court also cited academic literature on the ECMH. ${ }^{33}$ In short, the Supreme Court clearly chose to use efficiency as a characterization of the securities market. ${ }^{34}$ Numerous writers have noted the link between the plurality opinion in Basic and the semi-strong ECMH. ${ }^{35}$

Despite its analysis, the Basic Court offered little guidance to lower courts in construing the relationship between the fraud-onthe-market theory and the ECMH. ${ }^{36}$ As the lower courts have developed the doctrine, they have tightened the connection between the semi-strong version of the ECMH and fraud-on-the-market. The Third Circuit's decision in In re Burlington Coat Factory Securities Litigation ${ }^{37}$ displays one of the clearest commitments to the ECMH, describing an efficient market as one in which information "is immediately incorporated into stock prices," ${ }^{38}$ and citing articles linking the ECMH and the fraud-on-the-market theory. ${ }^{39}$ Other courts also have closely tied market efficiency to the presumption of reliance, though often not as rigorously as the Third Circuit. ${ }^{40}$ Nevertheless, courts frequently invoke descriptive

${ }^{32}$ Basic, 485 US at 241, quoting Peil, 806 F2d at 1160.

${ }^{33}$ Basic, 485 US at 246 n 24, citing Daniel R. Fischel, Use of Modern Finance Theory in Securities Fraud Cases Involving Actively Traded Securities, 38 Bus Law 1, 4 \& $n 9$ (1982); Roger J. Dennis, Materiality and the Efficient Capital Market Model: A Recipe for the Total Mix, 25 Wm \& Mary L Rev 373, 374 n 1, 374-81 (1984).

${ }^{34}$ The majority nevertheless recognized its lack of expertise: "We need not determine by adjudication what economists and social scientists have debated through the use of sophisticated statistical analysis and the application of economic theory." 485 US at 246 n 24. See also Part III.B.4.

${ }^{35}$ See Scudder, Comment, $92 \mathrm{Nw}$ U L Rev at 461 (cited in note 3) (asserting that "the presumption of reliance created by the fraud-on-the-market becomes incoherent if our markets are informationally inefficient"); Adams and Runkle, $145 \mathrm{U} \mathrm{Pa} \mathrm{L} \mathrm{Rev} \mathrm{at} 1109$ (cited in note 2) ("The Court [in Basic] based its adoption of the fraud-on-the-market theory on its implicit assumption of the validity of the principles underlying the ECMH."); Macey and Miller, 42 Stan L Rev at 1078 (cited in note 17) ("It is clear that the Supreme Court implicitly applied the semi-strong form of the ECMH in Basic.").

${ }^{36}$ See Abell v Potomac Insurance Co, 858 F2d 1104, 1120 (5th Cir 1988) ("Basic essentially allows each of the circuits room to develop its own fraud-on-the-market rules."), vacated on other grounds in Fryar $v$ Abell, 492 US 914 (1989).

${ }^{37} 114$ F3d 1410 (3d Cir 1997).

${ }^{38}$ Id at 1425.

${ }^{30}$ Id at 1415 n 1, citing Jonathan R. Macey, et al, Lessons from Financial Economics: Materiality, Reliance, and Extending the Reach of Basic v. Levinson, 77 Va L Rev 1017, 1017 (1991) (describing the relationship between the fraud-on-the-market theory and the ECMH); Fischel, 74 Cornell L Rev at 908-12 (cited in note 14) (same).

${ }^{40}$ See Wielgos $v$ Commonwealth Edison Co, 892 F2d 509, 510 (7th Cir 1989) (arguing that the Supreme Court adopted the fraud-on-the-market theory "because capital markets efficiently establish prices that embed available information"); O'Neil $v$ Appel, 165 FRD 
efficiency in the form of the semi-strong ECMH in litigation under Rule 10b-5.

However, despite the nearly universal acceptance of the proposition that the fraud-on-the-market theory and the ECMH are closely intertwined, a closer analysis of the efficiency requirement indicates that the ECMH plays a substantially smaller role than the post-Basic courts' language indicates. As discussed above, Basic uses the fraud-on-the-market theory in answering a simple question: Was the group of traders, as a whole, adversely affected by the defendant's fraud? If so, then they can recover, transforming the private action under Rule $10 \mathrm{~b}-5$ into the functional equivalent of fraud insurance. ${ }^{41}$ The fraud-on-the-market presumption thus depends on the probability that a firm's share price will respond to new information. If that probability is high, then the presumption makes sense, because in all likelihood, some traders acted on the incorrect information, thereby affecting market price.

Importantly, these traders need not respond to this information in a perfectly (or even largely) efficient manner. If the price movement was in the proper direction, it is sensible to apply the presumption. The theory does not require that the magnitude of such a response be perfect (as the semi-strong ECMH would predict). Hence, while the existence of an informationally efficient market is a sufficient condition for the fraud-on-the-market theory to make sense (because all the information is not only incorporated, but is incorporated to such a degree that further research is futile), it is not a necessary one. The justification for the fraud-on-the-market theory-facilitating the formation of a plaintiff class-asks a "yes or no" question about a security's response to fraudulent information. Justice Blackmun acknowledged this inquiry in Basic, noting that "we do not intend conclusively to adopt any particular theory of how quickly and completely pub-

479, 500 (W D Mich 1996) ("The linchpin of the fraud-on-the-market theory is the existence of an efficient market."); Kriendler $v$ Chemical Waste Management, Inc, 877 F Supp 1140,1150 n 8 (N D Ill 1995) ("Upon publication of the information, the market immediately reacts, adjusts, and incorporates the new information into the stock price."). There is some disparity in the circuit courts' tolerance for barriers to information dissemination. Compare Kaplan $v$ Rose, 49 F3d 1363, 1378 n 3 (9th Cir 1994) (discussing limitations on the flow of information into a market that is nevertheless efficient for purposes of establishing fraud-on-the-market, and observing that even an "efficient market will ignore irrelevant articles and articles that did not appear in sufficiently circulated and credible sources"), with Freeman v Laventhol and Horwath, 915 F2d 193, 198 (6th Cir 1990) (describing an inefficient market as one that "does not incorporate into its price all the available information about the value of a security").

${ }^{4}$ See Part II.C for further discussion of the insurance function of private Rule 10b-5 actions. 
licly available information is reflected in market price. ${ }^{\$ 2}$ In the end, the fraud-on-the-market theory captures a simple intuition-that "market professionals generally consider most publicly announced material statements about companies, thereby affecting stock market prices. ${ }^{\$ 43}$

2. Truth-on-the-market: a stronger application of the ECMH.

Courts' use of efficiency as a descriptive notion also appears in the counterweight to the fraud-on-the-market theory: the "truth-on-the-market" defense. This defense asserts that a plaintiff class cannot rely on the fraud-on-the-market theory to establish reliance when information correcting the fraudulent disclosure was readily available in the marketplace at the time of the fraudulent disclosure. If courts conclude that a market is efficient enough to support the fraud-on-the-market theory, then they must also conclude that the market is adept at incorporating publicly available corrective information into the price. Consequently, so long as the corrective disclosures had reached the marketplace by the time of the purchase or sale, the plaintiffs will not have paid a fraud-induced premium (or sold at a discount).

The truth-on-the-market defense has been described as a "corollary" of the fraud-on-the-market theory. ${ }^{44}$ In fact, the defense makes a much stronger claim about market efficiency than does the initial presumption of market reliance. Unlike the fraudon-the-market theory, truth-on-the-market involves a positive assertion regarding the magnitude of the market's response to new information. Suppose that both a misleading statement and corrective information are available to the market. To fulfill the requirements of fraud-on-the-market, it is only necessary to infer that the fraud affected the share price. The truth-on-the-market assertion, by contrast, declares that the corrective information offset any inflation caused by the defendant's fraud. To reach this outcome, it does not suffice to say that markets respond to infor-

${ }^{42}$ Basic, 485 US at $248 \mathrm{n} 28$.

${ }^{43}$ Id at $247 \mathrm{n} 24$. See also Langevoort, $140 \mathrm{U} \mathrm{Pa} \mathrm{L} \mathrm{Rev} \mathrm{at} 900$ (cited in note 1) (arguing that in the fraud-on-the-market theory, the "efficient market hypothesis is invoked, but in ways that on close inspection are neither necessary nor sufficient to the ultimate conclusion").

" See Associated Randall Bank v Griffin, Kubik, Stephens, and Thompson, Inc, 3 F3d 208, 214 (7th $\mathrm{Cir} 1993$ ) ("[T] truth-on-the-market corollary."); Wallace v Systems \& Computer Technology Corp, Fed Secur L Rep (CCH) II 99,578 at 97,868 (E D Pa 1997) ("An essential corollary to [the fraudon-the-market theory] is a truth on the market' defense."). 
mation. Rather, one must conclude that the corrective information affected the market as much as the misleading statement. Hence, the markets must respond completely and accurately to any information available. Viewed in this way, the truth-on-themarket defense mandates a substantially greater commitment to the semi-strong version of the ECMH than does the fraud-on-themarket theory. ${ }^{45}$

Courts applying the truth-on-the-market defense have given the claim varying degrees of potency. Some, clearly committed to the descriptive notion of market efficiency, have allowed the defense to negate a plaintiff's fraud-on-the-market claim simply because the information was available. ${ }^{46}$ Similarly, others have required plaintiffs to show that the alleged correcting information was not publicly available. ${ }^{47}$ In contrast, some courts have required defendants to show more than the mere availability of information, either allowing the factfinder to decide whether the correct information offset the fraud ${ }^{48}$ or, alternatively, requiring proof that the corrective information was disseminated with a sufficient degree of "intensity and credibility." Regardless of which formulation is applied, the truth-on-the-market defense presumes that the corrective information acts as a counterweight to the fraudulent statement or omission. Hence, it too applies the ECMH, invoking market efficiency as a descriptive concept.

\section{Heuristic Efficiency: Calculating Damages in Rule 10b-5 Cases}

The concept of efficiency also enters securities litigation when courts attempt to ascertain the damages suffered by investors who are victims of fraud. Here, efficiency is a heuristic tool rather than an attempt to describe the markets. Although Basic

${ }^{45}$ See Langevoort, $140 \mathrm{U} \mathrm{Pa} \mathrm{L} \mathrm{Rev} \mathrm{at} 905$ (cited in note 1) (noting that the truth-onthe-market defense "potentially makes a far stronger efficiency claim" than the fraud-onthe-market theory).

${ }^{46}$ See, for example, Roots Partnership $v$ Lands' End, Inc, 965 F2d 1411, 1420 (7th Cir 1992) (denying plaintiffs' claim because 'the fraud-on-the-market theory compels the conclusion that the price of Lands' End common stock reflected" the corrective information); Wielgos, 892 F2d at 515 (rejecting claim that defendants' failure to disclose the assumptions underlying cost projections in a prospectus led to fraud-on-the-market because "professional investors and analysts surely deduced what was afoot").

${ }^{47}$ See Kriendler, 877 F Supp at 1157 (rejecting claim based on nondisclosure of adverse industry trends because the trends "were known to the market and thus presumably to the Plaintiffs").

* See Saddle Rock Partners, Ltd v Hiatt, Fed Secur L Rep (CCH) I 99,413 at 96,701 (W D Tenn 1996).

${ }^{4}$ In re Apple Computer Securities Litigation, 886 F2d 1109, 1114-15 (9th Cir 1989); Wallace, Fed Secur L Rep (CCH) at 97,868 (adopting the Apple test). 
purported to leave the question open, ${ }^{50}$ the commonly accepted damages rule in Rule 10b-5 cases is the "out-of-pocket" theory articulated by Judge Sneed in his concurrence in Green $v$ Occidental Petroleum. ${ }^{51}$ Under this principle, plaintiffs are entitled to recover "the difference between the purchase price and the value of the stock at the date of purchase. ${ }^{.52}$ By taking the difference between what the share price was (as inflated by fraud) and what it would have been absent fraud, the theory "measures precisely the extent to which the purchaser has been required to invest a greater amount than otherwise would have been necessary. ${ }^{953}$ Thus, if the actual price after the fraud were $\$ 20$, and the price without fraud would have been $\$ 15$, a plaintiff buyer could recover $\$ 5$ per share purchased. This theory has been widely adopted in fraud-on-the-market cases. ${ }^{54}$

Irrespective of the particular method a court chooses, the court's role in assessing damages is to estimate-to the best of its ability-what the stock price would have been without the defendant's misleading statement or omission on the date of the statement or omission. Formally, this process does not require any presumption that a stock price is efficient in the information arbitrage sense..$^{55}$ The plaintiff's out-of-pocket damages are simply the difference between the price paid and what the price would have been absent fraud. If the ECMH is correct, then this price will accurately reflect all available information about the ability of the underlying assets to produce income. On the other hand, if the market is not informationally efficient, then those trading subse-

${ }^{50}$ Basic, 485 US at $248 \mathrm{n} 28$ ("[O]ur decision today is not to be interpreted as addressing the proper measure of damages in litigation of this kind.").

${ }^{61} 541$ F2d 1335, 1341 (9th Cir 1976) (Sneed concurring).

${ }^{62}$ Id at 1344. Green dealt with fraud that inflated the share price, thereby harming buyers. If the misleading statement or omission has a deflating effect, the difference between the sale price and value at the date of sale would be used instead.

${ }^{B}$ Id. Notice that any loss incurred by a defrauded purchaser is mirrored by a windfall gain for the seller. As a result, the issuer is cast into the role of insurer, despite enjoying none of the benefits of the fraudulent inflation.

${ }^{54}$ See, for example, Associated Randall Bank, 3 F3d at 214; In re Executive Telecard, Ltd Securities Litigation, 979 F Supp 1021, 1025 (S D NY 1997); Seagoing Uniforms Corp $v$ Texaco, Inc, 1989-90 Transfer Binder Fed Secur L Rep (CCH) II 94,791 at 94,257 (S D NY 1989).

so Fundamental value efficiency is irrelevant to damage calculations unless Judge Sneed's reference to "value" in Green is understood to require that the plaintiff receive the difference not between the price paid and what the price would have been, but rather between the price paid and what the price should have been. See Green, 541 F2d at 1344 (Sneed concurring). Yet there is no reason to believe that a plaintiff ought to recover more if the market otherwise overvalued the stock or less if stock was undervalued. The private Rule 10b-5 action is designed to protect buyers from the consequences of fraud, see notes 75-81 and accompanying text, not inefficiency. 
quent to the fraudulent statement may have been able to discover that the security was mispriced (for reasons other than the fraud itself). ${ }^{56}$ The out-of-pocket method of damage calculation is unaffected by either of these situations. The objective is merely to determine what price the plaintiff would have paid, not whether that price was a truly accurate reflection of the security's worth. As much as Rule 10b-5 damages are not designed to compensate (or penalize) plaintiffs for market departures from fundamental value, neither do they aim to assess the desirability of the stock as an investment absent fraud. ${ }^{57}$

Notwithstanding this distinction, many attempts to determine what the price would have been implicitly incorporate the ECMH's assumptions about the role of publicly available information. Hence, while the out-of-pocket damages theory (unlike either fraud-on-the-market or truth-on-the-market) does not necessarily incorporate a descriptive notion of efficiency, courts may presume that the market is efficient in order to determine the correct remedy. In this situation, efficiency is a heuristic device; while the market may be inefficient, courts have neither the time nor the expertise to determine whether this is the case.

At its simplest, the calculation of damages could involve a projection based on financial information and other data readily available on the date of the fraud. In essence, courts would pretend to be investment analysts, using tools such as the market model $^{58}$ to arrive at the share price. In doing so, however, the court implicitly accepts the ECMH because it asserts that the price would have been equal to the value that the available information suggested was appropriate. Typically, courts (or, more frequently, experts or special masters) use more sophisticated techniques to assess damages. The two most common are the "event study" and "comparable index" approach..$^{59}$ In the end, both

${ }^{s 6}$ Here, the challenge to market efficiency asks whether a trader would be able to earn superior returns by searching for information about the firm, industry, or economy, not by uncovering the defendant's deception. The role of corrective information in securities litigation and its relationship to courts' use of the ECMH is analyzed in the context of the truth-in-the-market defense to a fraud-on-the-market claim. See Part I.B.2.

${ }^{57}$ See note 14.

The market model describes the relationship between an individual stock's returns and market returns by positing a linear relationship between them and estimating the parameters (slope and intercept) through regression. See Adams and Runkle $145 \mathrm{U} \mathrm{Pa} \mathrm{L} \mathrm{Rev}$ at 1122-26 (cited in note 2) (describing the market model in greater detail).

50 The comparable index method involves constructing a "value line," i.e., the hypothetical price of the stock absent fraud over the period in question, by using the market model to work backwards from the disclosure date. The event study method, by contrast, assumes that the actual price and value line move in tandem except on days when fraudulent information entered the market. For a detailed discussion and critique of each 
of these techniques often incorporate a presumption of information efficiency.$^{60}$ The award presumes that the price of the stock on the date of the plaintiff's purchase, absent fraud, would have incorporated all of the information used by the court in making its determination of value. ${ }^{61}$ However, these methods do not represent an attempt to describe the operation of the securities markets. Rather, they serve as a heuristic tool-a "best guess" that, given the resources available to the court, facilitates the calculation process even if a court is suspicious of its ability to describe market operations precisely.

Efficiency thus appears in several forms in securities litigation: as a normative goal, as a descriptive assertion about market characteristics (through the use of the semi-strong ECMH), and as a heuristic device useful in calculating damages. The next Part turns to Congress, examining its treatment of market efficiency in its recent effort to curtail securities suits.

\section{CONGRESSIONAL TREATMENT OF MARKET EFFICIENCY IN THE PSLRA}

In 1995, Congress passed the PSLRA in an effort to stem the growth of what it perceived to be frivolous securities litigation. Both the statute and its legislative history have important implications for judicial presumptions of market efficiency. This Part argues that the PSLRA exhibits a decidedly atheoretical, practical approach to the regulation of the securities markets.

\section{A. Background and Objectives}

The PSLRA was enacted against a backdrop of legislative and regulatory efforts designed to promote the efficiency of the securities markets. Much of the normative use of efficiency discussed in Part I.A is traceable to Congress and the Securities and Exchange Commission ("SEC"). For example, the legislative history of the Securities Exchange Act of 1934 reflects Congress's desire to use securities regulation to improve capital markets' ability to reflect the value of underlying assets. The House Com-

method, see Bradford Cornell and R. Gregory Morgan, Using Finance Theory to Measure Damages in Fraud on the Market Cases, 37 UCLA L Rev 883, 897-911 (1990).

${ }^{60}$ See Langevoort, $140 \mathrm{U} \mathrm{Pa} \mathrm{L}$ Rev at 910 (cited in note 1) (arguing that both the comparable index and event study methods are "firmly and explicitly grounded in assumptions generated by the efficient market hypothesis").

${ }^{61}$ Actually, the court is assuming that its own chosen valuation method is correct. Consequently, not only does it assume that the price would have incorporated all of the information used by the court, but also that the market would have ignored information or valuation techniques not related to the method chosen in the litigation. 
merce Committee Report declares that "[j]ust as artificial manipulation tends to upset the time function of an open market, so the hiding and secreting of important information obstructs the operation of the markets as indices of real value. ${ }^{.62}$ Numerous scholars have noted the role that efficiency concerns play in the legislative and regulatory context. ${ }^{63}$ In large part, concern that existing litigation practices were impairing the ability of the disclosure system to improve market efficiency motivated the reform. effort underlying the PSLRA. ${ }^{64}$

Armed with statistical evidence of the frequency and magnitude of suits, ${ }^{65}$ as well as anecdotal evidence of frivolous or abusive litigation practices, ${ }^{66}$ Congress began considering legislation to reform securities fraud liability in early 1995. This effort culminated in the PSLRA, which had three objectives: (1) to encourage voluntary disclosure of information; (2) to "empower investors" so that they, not their lawyers, control litigation; and (3) to

a2 Securities Exchange Bill of 1934, HR Rep No 1383, 73d Cong, 2d Sess 11 (1934), reprinted in J.S. Ellenberger and Ellen P. Mahar, eds, 5 Legislative History of the Securities Act of 1933 and Securities Exchange Act of 193411 (Rothman 1973).

See Common Sense Legal Reforms Act of 1995, Hearings before the Subcommittee on Telecommunications and Finance of the House Committee on Commerce, 104th Cong, 1st Sess 204 (1995) (testimony of SEC Chairman Arthur Levitt) (arguing that the disclosure system has "led to fair and efficient markets in our country"); Securities Litigation Reform Proposals Hearings, S 240, S 667, and HR 1058 before the Subcommittee on Securities of the Senate Banking, Housing, and Urban Affairs Committee, 104th Cong, 1st Sess 13-14 (1995) (testimony of J. Carter Beese, Jr., Chairman of Capital Markets Regulatory Reform Project, Center for Strategic and International Studies) (noting that "a regulatory and legal structure that promotes liquidity, transparency, honesty, and efficiency" is necessary to encourage investment); Stout, 87 Mich L Rev at 621-22 (cited in note 13) (noting the increasing importance that the goal of efficiency plays in securities regulation). But see Frank H. Easterbrook and Daniel R. Fischel, Mandatory Disclosure and the Protection of Investors, $70 \mathrm{Va} \mathrm{L} \operatorname{Rev} 669,682-83$ (1984) (arguing that mutually beneficial bargains for information may be more effective than mandatory disclosure).

"See Common Sense Legal Reforms Act of 1995, HR Rep No 104-50, 104th Cong, 1st Sess 14 ("Congress enacted the Federal securities laws in 1933 and 1934 to protect investors and promote the efficient functioning of our capital markets. Today, private lawsuits under those statutes create precisely the opposite effect."); Securities Litigation Reform Proposals Hearings at 8 (statement of Senator Gramm during opening statement of Senator Domenici) ("[C]urrent practices are limiting the ability of the financial markets to work because companies are making decisions based on potential litigation costs instead of decisions that are driven by the marketplace to create jobs, growth, and opportunity for our people.").

${ }^{8}$ For example, a Senate Report claimed that although investors recover only "pennies on the dollar," over $\$ 1.4$ billion was paid out in settlements during 1994 alone, much of which went to plaintiffs' lawyers. S Rep No 104-98 at 9 (cited in note 20).

Securities Litigation Reform Proposals Hearings at 36 (statement of Senator Domenici) (noting the "cookie cutter" complaints alleging that Phillip Morris had attempted to "create and prolong the illusion of .. . success in the toy industry"). The case he wgs discussing is In re Phillip Morris Securities Litigation, 872 F Supp 97, 98 (S D NY 1995), affd in part and revd in part, San Leandro Emergency Medical Group Profit Sharing Plan $v$ Phillip Morris Cos, Inc, 75 F3d 801 (2d Cir 1996). 
encourage plaintiffs to pursue valid claims while simultaneously facilitating defendants' resistance to frivolous suits. ${ }^{67}$ These goals all reflect a commitment to creating efficient markets (i.e., normative efficiency). Disclosure is desirable because it facilitates the proper valuation of assets and thus permits an efficient allocation of society's productive resources. Provisions ensuring that investors, rather than lawyers, control the course of litigation enhance the ability of private actions to serve as efficient enforcement mechanisms by aligning control over litigation with the financial interests of defrauded shareholders, not their attorneys. ${ }^{68}$ Similarly, the provisions reducing plaintiff leverage improve the efficiency of the private action as an enforcement tool by strengthening defendants' ability to resist frivolous suits. ${ }^{69}$

\section{B. The PSLRA Damage Limitation Provisions: Challenging Descriptive Efficiency}

Among the most important PSLRA provisions reducing the plaintiff class's leverage in Rule $10 \mathrm{~b}-5$ suits is a limitation on the amount of damages available in fraud-on-the-market cases. Although it considered several alternatives, ${ }^{70}$ Congress settled on the following limitation:

Except as provided in paragraph (2), in any private action arising under this chapter in which the plaintiff seeks to establish damages by reference to the market price of a security, the award of damages to the plaintiff shall not exceed the difference between the purchase or sale price paid or received, as appropriate, by the plaintiff for the subject security and the mean trading price of that security during the 90-day period beginning on the date on which the information correcting the misstatement or omission that is the basis for the action is disseminated to the market. ${ }^{71}$

Through this provision, the PSLRA provides for a "look-back" period following the corrective disclosure so that plaintiffs will not

${ }^{67} \mathrm{~S}$ Rep No 104-98 at 5-6 (cited in note 20).

${ }^{6}$ The "most adequate plaintiff," 15 USC $\S 78 \mathrm{u}-4(\mathrm{a})(3)(\mathrm{B})(\mathrm{i})$, and settlement, 15 USC $\S 78 \mathrm{u}-4(\mathrm{a})(6)-(7)$, provisions are the primary mechanisms for achieving this goal. Elimination of the possibility of a "bounty" for lead plaintiffs with minimal holdings (and their attorneys) is designed to reduce the number of frivolous suits. See Private Securities Litigation Reform Act of 1995, HR Conf Rep No 104-369, 104th Cong, 1st Sess 6 (1995), reprinted in 1995 USCCAN 730, 734.

these provisions include more stringent pleading requirements as well as the damage limitation and safe harbor provisions discussed in Parts II.B and II.C, respectively.

${ }^{30}$ See Part II.C.

" PSLRA $\S 101,109$ Stat at 748-49, codified at 15 USC $\S 78 \mathrm{u}-4(\mathrm{e})(1)$. 
be overcompensated if the markets overreact to a disclosure correcting the initial misleading statement or omission. In arriving at this conclusion, Congress relied heavily on a "crash" theory of market movement posited by Professors Baruch Lev and Meiring de Villiers. ${ }^{72}$ This model predicts that share prices will systematically overreact and correct following a corrective disclosure. ${ }^{73}$

Acceptance of the Lev and de Villiers "crash" model of market movement subsequent to corrective disclosure suggests, for two distinct reasons, that Congress has rejected the semi-strong version of the ECMH. First, the damages provision suggests that Congress accepts that stock prices systematically rise (following the initial crash) after corrective information is disclosed. More precisely, prices rise more than those of other securities whose returns are comparably correlated to market returns. This increase suggests that a trading rule exists that would offer superior returns on a regular basis. By purchasing stocks immediately after a scandal is revealed, investors could, on average, "beat the market" - contrary to the ECMH's predictions.

Second, Congress apparently believes that price movement subsequent to the corrective disclosure is attributable not to new information entering the market, but rather to market readjustment following the initial overreaction to the unveiling of the fraud. Over the course of the ninety day postdisclosure "lookback" period, other macroeconomic, industry, and firm-specific information is likely to enter the market. Congress appears to think that price changes will be a reflection of both this new information and the response to the overreaction. Consequently, the damages limitation provision indicates that Congress, fully supportive of efficiency as a normative concept, is skeptical of its accuracy as a description of the markets. The next question, then, is whether Congress adopted an alternative theoretical approach to describe the operation of the financial markets.

\section{Congress Has Not Adopted a Theoretical Alternative to the ECMH}

The Lev and de Villiers proposal to which Congress referred in developing the limitation on damages posits a descriptive theory of price movements that is facially incompatible with the

${ }^{72}$ See S Rep No 104-98 at 20 \& n 58 (cited in note 20), citing Lev and de Villiers, 47 Stan L Rev at 22 (cited in note 14) (arguing that since "crash prices are not reliable indicators of true value, ... they should not be used to compute damages").

${ }^{73}$ Lev and de Villiers, 47 Stan L Rev at 13-17 (cited in note 14) (arguing that uninformed investors may react to others' trades, not the information itself, leading to continued selling even after the price reflects the new negative information). 
semi-strong ECMH. ${ }^{74}$ Congress, however, while looking to Lev and de Villiers, did not entirely adopt their theoretical model. Instead, Congress adhered to no particular theoretical model of market movement.

By creating an upper bound on the amount of damages that a plaintiff may recover, the PSLRA's limitation on damages promotes the goal of making private enforcement actions more efficient by allowing defendants to resist frivolous litigation with the knowledge that damages will be capped. This certainty also reduces plaintiffs' leverage in settlement negotiations. If Congress had been convinced that prices systematically crash following a corrective disclosure event, it would have prescribed a computation method in the PSLRA, given the desire to "rectify the uncertainty in calculating damages ${ }^{375}$ and simplify securities litigation. Moreover, the damages limitation provision in the PSLRA's companion bill also declined to adopt a computation method. ${ }^{76} \mathrm{By}$ declining to include such a method, Congress indicated a desire to limit plaintiffs' leverage and implement underlying policy goals, rather than to endorse a particular theory of market movement or pose an alternative to the ECMH. By imposing a "look-back"

"See id at 13 (noting that information asymmetry is at the heart of the crash theory).

${ }^{75}$ HR Conf Rep No 104-369 at 42, (cited in note 68). There is no reason to believe, that, in computing damages, courts will move away from the out-of-pocket approach or the event study and comparable index methods discussed in Part I.C. See note 59. The courts' practice led to uncertainty because, prior to trial, defendants do not know what parameters a court will use in constructing the value line or which dates will be used in an event study.

${ }^{78}$ The competing proposal read:

[T] he plaintiff's damages shall not exceed the lesser of-

the difference between the price paid by the plaintiff for the security and the market value of the security immediately after dissemination to the market of information which corrects the misstatement or omission; and

the difference between the price paid by the plaintiff for the security and the price at which the plaintiff sold the security after dissemination of information correcting the misstatement or omission.

S $240 \S 104,104$ th Cong, 1st Sess (Jan 8, 1995), in 141 Cong Rec S 1078 (Jan 18, 1995). In fact, the legislative history indicates that Congress may have hoped to create a calculation method. See S Rep No 104-98 at 28 (cited in note 20) ("Plaintiff's damages will be calculated" based on the bounce-back period); HR Conf Rep No 104-369 at 42 (cited in note 68) (stating that the provision "requires that plaintiff"s damages be calculated" using the lookback period). However, not only does the statutory language contradict this, but it would also make little sense to allow plaintiffs to benefit from further declines in market price after corrective disclosure. The more logical reading of this portion of the legislative history is that Congress assumed that, for simplicity's sake, the parties would choose to use the limit as a basis for entering settlement negotiations. Also, unlike the courts' techniques, the provision fails to take into account any movement attributable to a rising (or declining) market. See Part I.C. 
limitation, Congress simply ensured that if the stock price does crash and rebound, plaintiffs are not overcompensated as they would be if they received a damage award based on the stock's low point and could then obtain above-market returns after the crash. ${ }^{77}$

There is an exception to the limitation on damages that further reinforces the notion that avoidance of plaintiff overcompensation was the primary motivation behind the damages provision. The exception, which applies whenever a plaintiff sells during the ninety-day bounce-back period, provides that she may recover the difference between the purchase price and the near trading price for the period beginning from the time the fraud is disclosed and ending on the date of sale. Thus, if a plaintiff sells immediately, she is able to recover her entire loss on the security (purchase price less amount recovered upon sale). ${ }^{78}$ Recovery is allowed even if the share price crashes and rebounds following the corrective disclosure. Here, the break from Lev and de Villiers's theoretical approach is clear: they argue that because "crash damages" are not causally linked to the defendant's fraud, they should not be awarded. ${ }^{79}$ Because the PSLRA allows plaintiffs to recover "crash damages" by selling right after disclosure of the fraud, it is clear that the intent of Congress is simply to prevent plaintiffs from reaping the benefit of both the bounce-back (if any) and a damage award calculated on the basis of the immediate postdisclosure price. The private action continues to serve as insurance against fraud. Congress simply tried to ensure that shareholders recover only for losses actually sustained.$^{80}$ Hence,

"The legislative history indicates that this was Congress's primary concern. See HR Conf Rep No 104-369 at 42 (cited in note 68) ("Calculating damages based on the date corrective information is disclosed may end up substantially overestimating plaintiff's damages.").

73 The exact text of the exception provides that:

In any private action arising under this chapter in which the plaintiff seeks to establish damages by reference to the market price of a security, if the plaintiff sells or repurchases the subject security prior to the expiration of the 90-day period described in paragraph (1), the plaintiff's damages shall not exceed the difference between the purchase or sale price paid or received, as appropriate, by the plaintiff for the security and the mean trading price of the security during the period beginning immediately after dissemination of information correcting the misstatement or omission and ending on the date on which the plaintiff sells or repurchases the security.

15 USC § 78u-4(e)(2).

${ }^{79}$ See Lev and de Villiers, 47 Stan L Rev at 22-23 (cited in note 14) (arguing that, even if not fully compensated, investors should be denied crash damages "because there is an insufficient causal nexus between the crash and the fraud").

${ }^{80}$ There does not appear to be any provision in the statute to prevent a potential plaintiff from selling and then repurchasing the security in question (with the obvious risk that there will be no bounce-back in her particular case). Note also that the alternative provision was designed to preserve the insurance function of Rule 10b-5 litigation while 
the PSLRA's limitation on damages suggests that Congress has opted for a pragmatic approach to securities fraud that is designed to preserve the insurance function of the $10 \mathrm{~b}-5$ class action while improving the administration of claims rather than one that begins with any specific theory of market movement. ${ }^{81}$

Thus, the overall direction of the PSLRA is practical, not theoretical. Congress wanted to limit frivolous suits in order to improve the efficacy of private enforcement actions, thereby improving capital allocation-using efficiency in a normative, but not descriptive, fashion. ${ }^{82}$ Part III discusses how this atheoretical approach should affect judicial use of the ECMH.

\section{IMPLICATIONS OF CONGRESS'S ATHEORETICAL APPROACH}

\section{A. Courts Should Avoid Using the ECMH as a Descriptive Tool}

The PSLRA's text and its legislative history indicate that Congress is committed to the normative goal of making the securities markets more efficient. At the same time, Congress is skeptical about the ECMH's validity, but no more or less so than of any other attempt to describe the market's operation. The PSLRA reflects an approach to securities litigation that begins with a pragmatic goal-reducing the burdens that frivolous securities litigation places upon the capital markets. ${ }^{83}$ As a consequence, courts should be reluctant to use the ECMH as the foundation for analyzing securities actions, because they lack the institutional competence to make such judgments. As Justice White pointed out in Basic, "Congress, with its superior resources and expertise,

preventing overcompensation (by granting the plaintiff the lesser of the amount actually lost or the amount by which her losses could have been limited had she sold immediately following the corrective disclosure rather than continuing to hold the stock). See note 76.

${ }^{31}$ See Scudder, Comment, $92 \mathrm{Nw}$ U L Rev at 464 (cited in note 3) ("The Reform Act's damage provisions ... provide no coherent theory for limiting damages.").

${ }^{82}$ It could also be argued that Congress was motivated to pass the PSLRA by a desire to help a particular interest group-corporate issuers. However, it would be odd to include the sale price exception to the limitation on damages if the legislation were purely a product of competing political interests. Instead, Congress could prescribe a fixed cap, or even a calculation method that substantially limited damages. While a "public choice" explanation seems plausible for the anti-plaintiff' bar provisions discussed in notes 68-69 and accompanying text, it seems less plausible here. More importantly, such a motivation would nevertheless imply a pragmatic (if not as well-intentioned) approach, rather than a theoretical one.

${ }^{83}$ Alternatively, Congress could be viewed as merely having taken steps to protect public companies. Such a reading, at least in the context of the damages provision, seems less plausible than the claims administration-based interpretation of the limitation on damages discussed in Part II.C. More importantly, however, a public choice reading would nevertheless indicate a congressional predilection for a pragmatic, not theoretical, starting point in analyzing securities litigation. 
is far better equipped than the federal courts for the task of determining how modern economic theory and global financial markets require that established legal notions of fraud be modified. ${ }^{\text {"84 }}$ However, Congress, skeptical of the ECMH and other theories, declined to pass judgment and opted instead to emphasize policy results rather than descriptive efficiency. Hence, courts have no mandate to decipher the mysteries of stock price movements. ${ }^{85}$ Rather, the question of the securities markets' informational efficiency-fundamentally a question for financial economicsshould be left to financial economists. Courts, by contrast, should be restrained in using theory and take an approach that follows the policy-based approach put forth in the PSLRA's limitation on damages.

\section{B. The Fraud-on-the-Market Theory as a Presumption of Causation in an Active Market}

Initially, it might appear that because Congress rejected descriptive efficiency through the enactment of the PSLRA, courts should discontinue their use of the fraud-on-the-market theory. If courts do not rely on the semi-strong ECMH, then the presumption of reliance, rooted in a belief about how markets incorporate information, may also be inappropriate. Given congressional skepticism toward the ECMH (or any other theoretical model that attempts to describe the market), the fraud-on-the-market theory may be at odds with the PSLRA. Perhaps courts should reinstate the individual reliance requirement. At the same time, however, courts should be reluctant to abandon a theory that facilitates private actions, ${ }^{86}$ especially because Congress rejected a version of the securities litigation reform proposals that would have entirely eliminated fraud-on-the-market actions. ${ }^{87}$ Such actions are an "essential tool" in securities enforcement. ${ }^{88}$

* Basic, 485 US at 254 (White concurring in part and dissenting in part).

${ }^{\circ}$ Even if they did, Justice White pointed out that courts are probably not "in much of a position to assess which theories aptly describe the functioning of the securities industry." Id at 254-55.

* Of the few cases to reach the appellate level since the enactment of the PSLRA on December 22, 1995, none indicates that a court has changed its use of fraud-on-the-market in response to the statute. See, for example, Gilford Partners, LP v Sensormatic Electronics Corp, 1997 WL 757495, *7-8 (N D IIl) (analyzing a fraud-on-the-market claim without note of the PSLRA); Havenick $v$ Network Express, Inc, 981 F Supp 480, 522-24 (E D Mich 1997) (discussing the pleading requirements of the PSLRA, but never discussing the possibility that the fraud-on-the-market theory is no longer viable).

${ }^{87}$ See Common Sense Legal Reforms Act of 1995, HR $10 \S 204,104$ th Cong, 1st Sess (Jan 4, 1995) (requiring actual reliance in 10b-5 actions).

See Basic, 485 US at 231. 
Courts should resolve the tension between the PSLRA and descriptive efficiency not by abandoning the fraud-on-the-market theory, but rather by recharacterizing it in a way that does not require reliance on financial theory, but instead emphasizes probability. Such a move would require three distinct changes. First, the fraud-on-the-market theory should be understood as a presumption of causation, entirely subsuming the traditional reliance requirement. Second, the level of market activity, not efficiency, should be the focus of judicial inquiry. Third, courts ought to weigh the credibility and intensity of the misleading statement or omission, as many now do when considering the truth-on-themarket defense. ${ }^{89}$ These changes all emphasize practical inquiries that utilize courts' traditional areas of competence, rather than casting them into the world of theoretical financial economics.

\section{The fraud-on-the-market theory should invoke a presumption of causation, not reliance.}

Rather than interpreting fraud-on-the-market as a rebuttable presumption of reliance, courts should instead understand the theory as a method of proving causation. In invoking the presumption, a court would simply determine whether, as a matter of "common sense and probability," the defendant's fraud likely affected share price. The reliance requirement would thus be subsumed in the causation inquiry. A class of defrauded investors, able to establish a common sense presumption of causation, would not face any additional "reliance" requirement.

Understanding the fraud-on-the-market theory as creating a presumption of reliance is problematic because it forces courts to use the ECMH to describe market operations. The ECMH is part of the fraud-on-the-market theory because describing the presumption as "reliance on the integrity of the market price" entails a judgment about the operation of the market as a whole and an evaluation about its various participants' chances for success. Neither of these tasks is something at which courts are particularly adept. By focusing on causation, judges need not consider whether there was sufficient integrity in the market price to justify allowing the plaintiff class to move forward. Rather, courts applying the fraud-on-the-market theory would determine whether common sense dictates that the defendant's fraud caused the market price to change, not the degree to which the market accurately valued the new information. When it is clear that

\footnotetext{
See Part I.B.2.
} 
there is a "crooked crap game," the presumption is invoked; otherwise it is not. This proposal better utilizes the courts' institutional competence and better tracks congressional sentiments (as expressed in the PSLRA) by focusing attention on the particular circumstances surrounding the fraud rather than on disputed finance theory.

At first glance, this may appear to be a substantial doctrinal change. However, more careful analysis indicates that, while removing the reliance requirement will shift courts away from theoretical inquiries and toward a pragmatic approach, it does not represent a dramatic departure from existing practice. Several courts, both before and after Basic, have suggested such an understanding of the fraud-on-the-market theory. One early case, Blackie $v$ Barrack, ${ }^{91}$ recognized "that materiality directly establishes causation more likely than not, and that reliance as a separate requirement is merely a milepost on the road to causation. ${ }^{.92}$ In Eckstein $v$ Balcor Film Investors, ${ }^{93}$ Judge Easterbrook noted that:

The Supreme Court's adoption of the fraud-on-the-market doctrine in [Basic] shows that reliance is not essential; although Basic continued to use that word, it allowed an alternative method of establishing causation-an effect on market price-to support recovery by investors who never read the supposedly deceitful statement. ${ }^{94}$

Other courts confronting the fraud-on-the-market theory should follow this reformulation.

2. Emphasize activity, not efficiency.

In deciding whether to extend the fraud-on-the-market presumption of causation to the plaintiff class, courts must look at the level of activity, not efficiency, within the market. When considering causation, the focus of courts' inquiry should rest on the probability that a statement affected market price. ${ }^{95}$ Thus, in order to take advantage of the fraud-on-the-market theory and es-

${ }^{\circ}$ Basic, 485 US at 247, quoting Schlanger v Four-Phase Systems Inc, 555 F Supp 535, 538 (S D NY 1982).

" 524 F2d 891 (9th Cir 1975).

$\because$ Id at $906 \mathrm{n} 22$.

20 8 F3d 1121 (7th Cir 1993).

$*$ Id at 1129 (citations omitted). See also Grossman $v$ Waste Management, Inc, $589 \mathrm{~F}$ Supp 395, 400 (N D Ill 1984) (discussing the relationship between reliance and causation).

$\approx$ The ECMH, of course, allowed courts to avoid this inquiry because it posits not only that statements are incorporated into price, but that publicly available information will be properly valued. Without this presumption, further inquiry is necessary. 
tablish that common issues of law and fact (particularly related to the misrepresentation, scienter, and damages elements of a 10b-5 claim) predominate, plaintiffs must show that a security was widely traded during the period in question. This factual inquiry allows courts to make a common sense judgment that, with all the traders out there, a substantial number used the fraudulent information.

Courts have already developed the tools necessary to conduct this fact-based inquiry. The commonly accepted requirements for plaintiffs seeking to invoke the fraud-on-the-market doctrine were first articulated in Cammer $v$ Bloom..$^{96}$ There, the court considered five criteria: (1) average weekly trading volume; (2) the number of securities analysts who regularly follow the stock; (3) the number of market makers for the stock; (4) whether the company was qualified to file an S-3 registration statement; and (5) past indications that disclosures of information caused the share price to move. ${ }^{97}$ All of these criteria measure one basic attributethe degree of activity in the market for the stock. ${ }^{98}$ Thus, courts should balance these factors in deciding whether the probability that the information affected price is sufficiently high, such that common sense would dictate that the plaintiffs were probably wronged. Hence, courts are well equipped to conduct a causation inquiry. These factors all relate to their basic factfinding function, rather than forcing them to adopt a particular financial theory.

\section{Incorporate the "credibility and intensity" requirement.}

The effect of requiring an active market is to increase the probability that the allegedly misleading statement or omission affected the trading price of the security, thereby making the causation presumption more sensible. If courts, however, no longer assume the existence of the rapid and comprehensive information processing that is predicted by the ECMH, then they

711 F Supp 1264 (D NJ 1989).

${ }^{97}$ Id at 1286-87. A number of courts have adopted the Cammer test. See, for example, Hayes $v$ Gross, 982 F2d 104, 107 n 1 (3d Cir 1992); Freeman, 915 F2d at 198-99; Simpson v Specialty Retail Concepts, 823 F Supp 353, 354 (M D NC 1993); In re Sahlen and Associates, Inc Securities Litigation, 773 F Supp 342, 356-57 (S D Fla 1991); In re MDC Holdings Securities Litigation, 754 F Supp 785, 804 (S D Cal 1990).

${ }^{38}$ Eligibility for S-3 filing depends on market capitalization, not activity. Nevertheless, it is fair to assume a substantial correlation between market capital, which S-3 eligibility does indicate, and market activity, the focus of the test. At least one court has described the theory as requiring an "active" market. See Abell, 858 F2d at 1121 (allowing reliance on the theory when "the plaintiff can establish that the subject securities were traded on an active secondary market'). 
must conclude that the likelihood that a defendant's statement affected a share's price depends on its credibility and on the intensity with which it was disseminated. ${ }^{99}$ Hence, courts should consider these factors when deciding whether to permit the plaintiff class to enjoy a presumption of causation. If the allegedly fraudulent statement is so far-fetched (such as an announcement of dramatically higher earnings) as to raise doubts as to its validity, then the probability that it had a material effect on price is low-even in an active market. Similarly, a widely publicized statement (such as one made in a press conference or published in a major newspaper) is more likely to have affected share price than one that received little attention.

The consideration of credibility and intensity represents a substantial change in the construction of the fraud-on-the-market theory, ${ }^{100}$ but it builds on two existing judicial practices in Rule 10b-5 litigation. First, it is a straightforward extension of the intensity and credibility requirement imposed by the Ninth Circuit in In re Apple Computer Securities Litigation. ${ }^{101}$ There, defendants asserting a truth-on-the-market defense were required to show that the corrective information was released with sufficient credibility and intensity. ${ }^{102}$ Plaintiffs asserting a fraud-on-themarket claim should be required to make a similar demonstration regarding the allegedly fraudulent statement or omission. Given Congress's skepticism toward the ECMH, it is sensible to deny both sides the opportunity to rely on it in establishing that the information in question affected share price. Hence, both plaintiffs and defendants should be subject to an assessment of the credibility and intensity of the information that each uses to bolster its side.

Second, the requirement that plaintiffs show that the allegedly fraudulent statement was credible builds on the "bespeaks caution" doctrine developed by courts to shield defendants who accompany their statements with appropriate caveats. Under this rule, reliance on projections, despite an issuer's warnings against doing so, is per se unreasonable. ${ }^{103}$ Unlike the bespeaks caution

" Under the semi-strong ECMH, the market is assumed to discount properly all information for any possible lack of credibility (i.e., other investors could not, through investigation, determine that the market had overvalued or undervalued the statement). The same is true for intensity-under the ECMH, all information is impounded into price, irrespective of whether it appears on the front page or in the fine print.

${ }^{100}$ A search of cases revealed no court that has applied these factors to a plaintiff's fraud-on-the-market claim.

${ }^{101} 886$ F2d 1109 (9th Cir 1989). See Parts I.B.2 and III.C.

${ }^{102}$ Id at 1114

${ }^{100}$ See, for example, Parnes $v$ Gateway 2000, Inc, 122 F3d 539, 548 (8th Cir 1997) 
doctrine, however, the credibility requirement proposed here shifts attention away from the reasonableness of actual reliance and focuses on the probability that the statement had an effect on price. Furthermore, unlike the proposed solution, which focuses on probability, the existing doctrine leaves only two options-either the required cautionary language or context is present (in which case the defendant's statement is not actionable), or it is not (in which case the doctrine is irrelevant). ${ }^{104}$

It is thus possible for courts to take an atheoretical approach to the fraud-on-the-market presumption by focusing on causation, rather than reliance. They should weigh all of the factors affecting the probability that a fraudulent statement had an effect: market activity, intensity, and credibility. Not only will courts better utilize areas of traditional institutional competence (factfinding and assessing credibility), but they have also already developed many of the necessary tools.

\section{Advantages of this reformulation.}

This proposed understanding of the fraud-on-the-market theory offers several advantages over the current model. First, it limits courts' rhetorical use of the ECMH. Second, it prevents courts from being forced to make determinations outside of their area of expertise. Third, it aligns the fraud-on-the-market theory with Congress's pragmatic approach to private securities actions.

As discussed above, adherence to the ECMH is not critical for the fraud-on-the-market theory. Rather, courts appear to apply it for largely rhetorical reasons. ${ }^{105}$ As one commentator has explained, because Basic invoked the concepts of finance theory, its

(noting that cautionary statements can render forward-looking statements immaterial); In re Donald J. Trump Securities Litigation, 7 F3d 357, 371-72 (3d Cir 1993) (requiring "the cautionary statements [to] be substantive and tailored to the specific future projections, estimates or opinions in the prospectus which the plaintiffs challenge"); In re Worlds of Wonder Securities Litigation, 814 F Supp 850, 858-59 (N D Cal 1993), affd in part and revd in part, 35 F3d 1407 (9th Cir 1994) (applying the bespeaks caution doctrine to optimistic projections in issuer's prospectus). Other courts have looked more broadly, analyzing the context of the statement. See, for example, Epstein $v$ Washington Energy Co, 83 F3d 1136, 1141 (9th Cir 1996) (analyzing the regulatory context of defendant's predictions).

${ }^{104}$ No court appears to have "split the difference"; all treat bespeaks caution as a threshold question. See, for example, Epstein, $83 \mathrm{F3d}$ at 1141 ("[R]eliance on predictive statements in the context of regulatory proceedings is inherently unreasonable [and thus not actionable]."); In re Worlds of Wonder, $814 \mathrm{~F}$ Supp at 859 ("Estimates or forecasts of future performance in a prospectus are not actionable if the prospectus contains conspicuous language that bespeaks caution as to actual results.").

${ }^{105}$ See Langevoort, $140 \mathrm{U} \mathrm{Pa} \mathrm{L} \mathrm{Rev} \mathrm{at} 856$ (cited in note 1) (noting that use of the $\mathrm{ECMH}$ is "often more rhetorical than real"). 
"reasoning took on the aura of intellectual inevitability." The use of the ECMH as justificatory rhetoric raises two concerns. First, even if the theory plays a minor role in the doctrines in which it appears, the use of the ECMH endorses a particular view of how markets operate. By starting with a presumption that the ECMH is correct, courts will frame future doctrinal debates within the confines of a particular economic theory. Other possible analyses that presume inefficient markets may be excluded before they are considered. ${ }^{107}$ Given their lack of democratic accountability, as well as their limited expertise in the area, courts should abstain from this type of advocacy. Additionally, the continued use of a descriptive notion of efficiency in the fraud-on-themarket context may lead to a broader role for the ECMH-particularly in the takeover and corporate governance areas. ${ }^{108}$ The proposed reformulation offers the benefit of reducing the judiciary's rhetorical use of finance theory.

Another advantage of the suggested reconstruction of the fraud-on-the-market theory is that it minimizes the opportunity for litigants to force courts to decide questions of finance theory rather than fact. By including the ECMH in the fraud-on-themarket theory, courts have given defendants the opportunity to claim that periods of excess volatility and seemingly inexplicable price movements indicate that the market for a particular security is inefficient, thereby making the presumption of reliance on the integrity of the market price improper. ${ }^{109}$ Analyzing this claim requires courts to drift far from their institutional competence. Moreover, it requires the courts to delve into a subject area-finance theory-the problems of which Congress, the more competent institution, has been unable to resolve.

${ }^{106}$ Id at 902. See also Donald N. McCloskey, The Rhetoric of Law and Economics, 86 Mich L Rev 752, 761 (1988) (arguing that economic vocabulary is sometimes used "to evoke a sense of scientific power, to claim precision without necessarily using it").

${ }^{10}$ See Donald N. McCloskey, The Consequences of Rhetoric, in Arjo Klamer, Donald N. McCloskey, and Robert M. Solow, eds, The Consequences of Economic Rhetoric, 280, 28690 (Cambridge 1988) (discussing the importance of rhetoric and word choice in guiding economic debate).

${ }^{106}$ See Langevoort, $140 \mathrm{U} \mathrm{Pa} \mathrm{L} \mathrm{Rev} \mathrm{at} 914$ (cited in note 1) (expressing concern that regulators and judges may "thoughtlessly reify [market efficiency] rhetoric, in areas such as the regulation of takeovers or the role of shareholder monitoring").

${ }^{100}$ While the emphasis on market activity in the Cammer factors, see notes $96-97$ and accompanying text, may preclude this type of claim from succeeding, many courts' articulation of the fraud-on-the-market theory requires that information be accurately, as well as rapidly, incorporated into stock price. See, for example, In re Burlington Coat Factory, 114 F3d at $1419 \mathrm{n} 8$ (attributing this position to Basic). Indeed, one of the litigants in Cammer tried to make this argument. See $711 \mathrm{~F}$ Supp at 1281 (noting defendant's argument that "there has never been a rigorous economic study of the efficiency of the overthe-counter market”). 
In addition, the PSLRA's damage limitation provision reflects a desire to allow private actions to continue to act as "fraud insurance."110 By concentrating on the probability that the defendant's fraud was responsible for the plaintiffs' losses, the proposed reform allows courts to be effective claims administrators. Otherwise, market inefficiencies could lead to judicial error-either by allowing plaintiffs to recover when common sense dictates that the likelihood of an effect was small, or by denying recovery when the corrective disclosure was unlikely to have been effective.

Perhaps most importantly, focusing the fraud-on-the-market theory on probability aligns courts' actions with Congress's policy goals, and adheres to Basic's description of the role of judicial presumptions. ${ }^{111}$ As the Senate Committee Report on the PSLRA indicates, Congress believed that the federal courts had allowed frivolous securities litigation to undermine, rather than further, public welfare. ${ }^{12}$ The plaintiff's additional requirements-showing credibility and intensity-will deter suits based on puffery and trivial statements without adversely affecting those based on legitimate grievances. Thus, the proposed reformulation serves the express congressional goal of tightening the restrictions on securities class action plaintiffs. At the same, it incorporates the policy goals underlying Basic and congressional skepticism towards the ECMH.

Courts may be concerned that by eliminating the reliance requirement, they would undercut Congress's chosen path in the PSLRA-reducing plaintiff leverage. At first glance, removing an element should make a case easier to prove. Here, however, this is not the case. First, the proposed reformulation will focus courts on legitimate harms caused by fraud. By emphasizing the level of market activity, as well as the credibility and intensity of the al-

${ }^{110}$ See Part II.C.

"I See Basic, 485 US at 245 (describing four purposes for presumptions: fairness, judicial economy, probability, and public policy). If implicated at all, considerations of fairness and judicial economy seem to weigh in favor of the proposed changes. Plaintiffs and defendants will face similar hurdles and courts will be left with an atheoretical inquiry more suited to their institutional competence. Admittedly, however, assessing the mix of market activity, credibility, and intensity could involve complex considerations, thereby raising decision costs. At least one lower court has noted this point. See Gilford Partners, 1997 WL 757495 at $* 7 \mathrm{n} 5$ ("The Court noted that it was not necessarily accepting the validity of any particular version of the [ECMH] .... Instead, it adopted the general assumption based upon considerations of probability, judicial economy and the public policy underlying the Exchange Act.”).

${ }^{112}$ See S Rep No 104-98 at 4 (cited in note 20) (claiming that the judiciary has created "substantial uncertainties and opportunities for abuses of investors, issuers, professional firms and others"). 
legedly fraudulent statement, ${ }^{113}$ courts can help to eliminate the frivolous suits targeted by Congress in a way consistent with its pragmatic approach. Because a court will refrain from making anything other than a common sense judgment about the market, plaintiffs will be able to move forward only in cases of clear fraud. More fundamentally, however, the reliance "requirement" does not place a meaningful burden on plaintiffs. The fraud-on-themarket theory treats reliance on the integrity of the market as a goal of securities regulation, ${ }^{114}$ not a requirement for members of the plaintiff class. In other words, reliance in fraud-on-themarket cases concerns a right to rely on a belief that the market is free of fraud, not an element in a significant sense. ${ }^{115}$ Thus, taking a policy-based, rather than theoretical, approach does not risk reopening the floodgates that the PSLRA was in large part designed to close.

\section{Rebutting the Presumption: Truth-on-the-Market}

Because the truth-on-the-market defense makes more extensive use of the ECMH than does the basic fraud-on-the-market claim, ${ }^{116}$ it might appear to make it difficult for courts to remove descriptive efficiency from Rule $10 \mathrm{~b}-5$ litigation. In fact, the proposed reformulation of the fraud-on-the-market theory greatly simplifies its truth-on-the-market corollary. As discussed above, ${ }^{117}$ the activity requirement rests on the simple premise that as the market becomes more active, the probability that the fraud affected price increases. The same is true for corrective disclosures. Courts should focus on the point at which the presence of truth-adjusted for intensity, credibility, and the level of market activity-makes the causal relationship between fraud and price no longer a matter of "common sense," scriptive judgment about market operations that requires specialized competence that courts generally lack. Hence, plaintiffs

${ }^{113}$ See Parts III.B.2 and III.B.3.

"I'See Basic, 485 US at 246 (noting that the disclosure requirements are designed to "facilitate an investor's reliance on the integrity of those markets"); Blackie, 524 US at 907 ("The statute and rule are designed to foster an expectation that securities markets are free from fraud-an expectation on which purchasers should be able to rely.") (emphasis added).

${ }^{115}$ See, for example, Fischel, 74 Cornell L Rev at 918-19 (cited in note 14) (discussing the irrebuttability of the fraud-on-the-market presumption and showing that Basic's own exceptions involve cases where no fraud has occurred).

${ }^{118}$ See Part I.B.2.

${ }^{\text {"II }}$ See Part III.B.

${ }^{118}$ Again, this is the essence of Blackmun's fraud-on-the-market opinion. See Basic, 485 US at 246. 
will be able to move forward using the fraud-on-the-market theory only when it is clear that the defendant's fraudulent assertion is likely to have affected price and was not counteracted by corrective information already in the market at the time of the fraud. Although this may appear to be an overly harsh rule that will exclude meritorious cases, it seems unlikely that it will deter many plaintiffs who are victims of intentional fraud, the conduct against which Congress seems most eager to protect. ${ }^{119}$ It is doubtful that issuers who are trying to mislead investors will do so with statements that more than a small handful of insiders know to be false.

In essence, the truth-on-the-market defense uses the same argument that underlies the position that a fraud-on-the-market claim should depend on activity, not efficiency; in an active market, information (either corrective or misleading) is likely to affect price. Determining the relative level of those two effects (fraudulent information and corrective disclosure) is beyond the courts' inherent competence and is a project even Congress is reluctant to undertake. Under this proposed change to the fraud-on-themarket theory, courts would deny plaintiffs the advantage of the presumption when the level of corrective information raises a significant doubt about the effect of the fraud on share price, thereby forcing the court to make a descriptive judgment about market efficiency. Thus, the truth-on-the-market theory should remain a defense, not for the ECMH-based reasons articulated by the courts; but because it undercuts the probability of causation on which the fraud-on-the-market theory should depend.

\section{The Heuristic Efficiency Problem}

Congress's apparent turn away from finance theory also creates a dilemma for courts attempting to determine damages in securities fraud cases. Clearly, the use of efficiency as a normative concept makes sense and remains consistent with legislative direction. On the other hand, efforts to describe the market using the ECMH seem contrary to Congress's atheoretical approach and, more specifically, to its concern that markets will systematically overreact to corrective disclosures. Damage calculation methods, however, do not claim that the market is truly efficient; they merely assume efficiency because courts lack the expertise

${ }^{119}$ See PSLRA $\S 101,109$ Stat at 747, codified at 15 USC $\S 78 u-4(b)(2)$ (requiring plaintiffs to plead with particularity facts relating to the defendant's state of mind); id at $\S 201$, 109 Stat at 758, codified at 15 USC $\$ 78 \mathrm{u}-4(\mathrm{~g})(2)(\mathrm{A})$ (imposing joint and several liability only on defendants who knowingly make fraudulent statements). 
necessary to determine the effect, if any, of market inefficiencies. If Congress truly does not believe in the ECMH, then it might seem that courts should not only refrain from doctrinal approaches that attempt to describe the market as efficient, but should also avoid using efficiency as a heuristic device.

In the end, however, the changes in the fraud-on-the-market doctrine proposed by this Comment-and their relationship to the truth-on-the-market defense- do not imply that courts must find new methods to calculate damages. Using the ECMH in damage calculations is problematic only if the goal of the out-of-pocket method is something other than simply predicting the security's price absent fraud at the time it was purchased. The core insurance function of the out-of-pocket approach requires only a best guess; it is entirely possible that the stock was overvalued or undervalued (for reasons other than the fraudulent statement) when the defrauded plaintiff purchased it. As noted in Part I.C, the ECMH is not crucial to the doctrinal basis for the out-ofpocket approach to damages; it is employed only for lack of a better method. The same institutional competence concerns that should lead courts to abandon their use of efficiency as a descriptive concept should also lead them to continue to employ efficiency as a heuristic device in order to calculate damages. Unable to make sophisticated judgments about the financial markets, courts should be as wary of embarking on efforts to find better methods of predicting stock prices as they are of attempting to draw a general conclusion about the market's condition.

The case for continued use of efficiency as a heuristic device is even stronger in the context of reviewing settlements. ${ }^{120}$ If the two sides reach an agreement that is fair and reasonable, but that nevertheless appears to use an efficiency-dependent method for calculating damages, nothing in the PSLRA indicates that courts should question this judgment. ${ }^{121}$ Thus, courts should re quire only that the market's estimate be reasonable, not precisely accurate. Share prices might be biased in a particular direction; this bias could be uncovered with further analysis of publicly

${ }^{120}$ This is, in practical terms, a far more significant context than that of fixing damages because an overwhelming majority of securities fraud cases settle if plaintiffs are able to pass the summary judgment stage. See Janet Cooper Alexander, The Value of Bad News in Securities Class Actions, 41 UCLA L Rev 1421, 1422 (1994) (noting that most securities fraud actions settle rather than go to trial).

${ }^{122}$ When deciding whether to approve a proposed settlement, courts must examine whether the proposal is "fundamentally fair, adequate, and reasonable." In re Clearly $\mathrm{Ca}$ nadian Securities Litigation, 966 F Supp 930, 932 (N D Cal 1997), quoting Torrisi v Tucson Electric Power Co, 8 F3d 1370, 1375 (9th Cir 1993). 
available information. However, in the settlement context, the parties have consented to the market's valuation, whatever errors and biases (if any) it may reflect. Consequently, unless there is reason to suspect a substantial flaw in the price-setting process, courts should defer to parties' choice of the market as a tool for determining value. Excess volatility (an unusually high variance in returns), a dramatic movement in the overall market price level (especially a crash), or a major political crisis triggering economic uncertainty could give a court reason to inquire further. However, absent such circumstances, courts are unlikely to do better than the parties.

\section{CONCLUSION}

Market efficiency appears as a normative, descriptive, and heuristic concept in securities litigation. This Comment has argued that there is a conflict between courts' use of efficiency to describe the markets (through their adherence to the ECMH) and the damages limitation provisions in the PSLRA, which reflect a congressional desire to limit plaintiffs' leverage and ensure that defrauded plaintiffs are not overcompensated by market overreactions. Given Congress's commitment to these objectives, courts should take notice.

The best approach for responding to the PSLRA is to remove the ECMH from the fraud-on-the-market theory. The theory should be treated as a common sense presumption that arises with a showing of a sufficiently active market along with credible and widely dispersed information. Simply put, fraud is likely to cause a change in the price at which investors buy or sell securities in an active market. As a consequence, there is no reason for courts to rely on theories that describe the market as efficient. Instead, using "common sense and probability,"122 courts should attempt to ensure that no investor must "roll the dice in a crooked crap game."123

${ }^{122}$ Basic, 485 US at 246.

${ }^{123}$ Id at 247, quoting Schlanger, 555 F Supp at 538. 